\title{
レーザークーロン爆発イメージングによる実時間反応追跡
}

\author{
菱川明栄 \\ 名古屋大学大学院 理学研究科物質理学専攻 (化学系) ( T464-8602 愛知県名古屋市千種区不老町)
}

\section{Real-Time Reaction Probing by Laser Coulomb Explosion Imaging}

\author{
Akiyoshi HISHIKAWA \\ Department of Chemistry, Graduate School of Science, Nagoya University, Furo-cho, Chikusa, Nagoya, Aichi 464-8602
}

(Received June 15, 2012)

\begin{abstract}
Molecules exposed to few-cycle intense laser fields $\left(>10^{14} \mathrm{~W} / \mathrm{cm}^{2}\right)$ undergo a rapid bond breaking process called Coulomb explosion. Since the momenta of the resultant fragment ions reflect the geometrical structure of the target molecule, Coulomb explosion provides a direct access to the instantaneous structure of molecules during chemical reaction. Combined with the pump-probe scheme in ultrafast spectroscopy, Coulomb explosion imaging serves as a unique means to probe ultrafast molecular reaction processes in real time. Here we review this novel approach in ultrafast spectroscopy, with the applications to ultrafast isomerization of deuterated acetylene dication $\left(\mathrm{C}_{2} \mathrm{D}_{2}{ }^{2+}\right)$.
\end{abstract}

Key Words: Laser Coulomb explosion, Intense laser fields, Few-cycle laser pulse, Ultrafast spectroscopy, Hydrogen migration

1. はじめに

反応過程において刻一刻と変化する分子の姿を捉える ことは，化学反応を理解し，更にそれを制御するために 最も基本的かつ重要な課題である. フェムト秒領域の超 短パルスレーザーを用いた超高速分光法 ${ }^{1)}$ はこの目的に 対して極めて有力であり，ポンプ光で生成した分子の核 波束を, 波長チューニングしたプローブ光で他の電子状 態に射影することで，超高速で進行する分子ダイナミク スが追跡できる。この手法はこれまでに簡単な 2 原子分 子のみならず，生体関連物質などの大規模な分子に適用 され，大きな成果を挙げてきた。一方，ここでの観測量 はプローブ光の吸収強度の時間変化であり, どのように 分子の形が変化しているかを観測データから理解するた めには，核波束が発展する電子状態，およびそれを射影 する電子状態のポテンシャル曲面についての詳細な知見 が必要である。特に異性化反応のように大きな分子構造 を伴うダイナミクスの追跡のためには, 多次元ポテン シャルの地形を広い範囲にわたって知っておく必要があ る。

反応過程を分子構造変化として直接観測する手法とし て，電子線やX線パルスを利用したアプローチが進めら れ成功を収めている年)。 これに対して, 高強度極短 レーザーパルスによるクーロン爆発を利用した実時間反 応イメージングは, 電子線やX線回折で捉えることが難 しい軽元素の運動を高い時間分解能で追跡可能な手法と
して注目されている。この手法では, サブ10フェムト秒 領域の極短強レーザーパルス $\left(\sim 10^{14} \mathrm{~W} / \mathrm{cm}^{2}\right)$ を照射する ことによって生成した多価分子イオンからの強いクーロ ン反発による速やかな解離 $=\lceil$ 「ロン爆発」を利用す る。クーロン爆発によって生成したフラグメントイオン の運動量ベクトルは爆発直前の分子構造によって決まる ため，イオン運動量を計測することによってレーザー照 射時における分子構造のスナップショットが得られる. これをポンプープローブ計測と組み合わせることによっ て, 反応過程における分子ダイナミクスを構造の変化と して捉えることができる。

\section{2. クーロン爆発イメージング}

\section{1 原理}

強いレーザーパルスを分子に照射すると複数の電子が 速やかにはぎ取られ，大きな電荷を持つ多価分子イオン が生成する。この分子は電荷間の強いクーロン反発に よって解離を起こす ${ }^{5-7)}$ 。これが「クーロン爆発」と呼ば れる現象である。クーロン爆発で生成したフラグメント イオンの持つ運動量は爆発直前の分子構造およびダイナ ミクスを鋭敏に反映することが知られている(Fig. 1). これは夜空に輝く花火の形が，星(火薬玉)がどのように 尺玉の中に配置されていたかによって決まることに対応 している.

こうしたクーロン爆発過程は強レーザーパルスとの相 


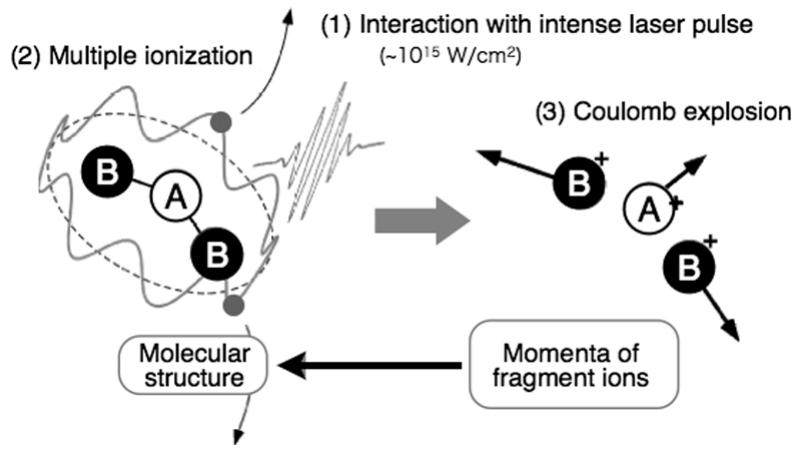

Fig. 1 Coulomb explosion in intense laser fields: (1) interaction with an intense laser pulse, (2) multiple ionization, leading to (3) rapid dissociation from multiply charged states, called Coulomb explosion. Momenta of fragment ions reflect the geometry of the molecule just before Coulomb explosion.

互作用だけでなく, 分子と多価原子イオンとの衝突や, 加速器を用いて得た $\mathrm{MeV}$ 領域分子イオンビームと炭素 などの薄膜 (フォイル)との衝突等でも観測される.すべ てのフラグメントのイオン価数が十分大きければ，それ ぞれのフラグメントイオンが最終的に持つ速度ベクトル (あるいは運動量)を, 元の分子構造から古典軌道近似に よって計算することができる。一つの分子から生成する すべてのフラグメントイオンを同時に検出し，それぞれ の持つ運動量を決定すれば, 元の分子構造を3次元で再 構築できる. 対象とする分子のアンサンブルについて計 測を行うことによって, 分子構造の分布関数が得られ， どの方向に相関を持って分子構造が摇らいでいるかを調 ベることができる。

分子構造を決定する手法として, クーロン爆発イメー ジングによるアプローチは直接的でモデルに対する依存 性が比較的少ない。ただ, 精密な構造決定にはいくつ か考慮すべき点がある。前述したようにクーロン爆発は 多価分子イオンからおこるが，元の分子構造を保ったま ま多価分子イオンを生成するためには, 多重イオン化過 程は分子の運動時間スケールに対して十分速やかでなけ ればならない.フォイルを用いた多重イオン化では, 分 子ビームがフォイルを通過する時間が数10アト秒程度と 極めて短いため, この条件が良い近似で満たされてい る. 構造を再構築する際に, フラグメントイオン間のポ テンシャルは完全なクーロンポテンシャルであると仮定 され，化学結合がクーロン力に比べて無視できなければ ならない。このためには, 大きな分子ほどより多価の分 子イオンの生成が必要である。また一般に，フラグメン トの運動量から分子構造を一意に決定することはできな い.このため再構築によって得られた構造の中から意味 のある解を選びだす必要がある。

\section{2 強レーザー場におけるクーロン爆発}

時間幅100 fs, エネルギー $1 \mathrm{~mJ} / \mathrm{pulse}$ のレーザー光を半 径10 $\mu \mathrm{m}$ のスポットに集光した場合, 焦点での平均強度 として $1 \mathrm{~mJ} /\left[\pi(10 \mu \mathrm{m})^{2} \times 100 \mathrm{fs}\right]=3.2 \times 10^{15} \mathrm{~W} / \mathrm{cm}^{2}$ が得 られる。このレーザー場の電場の大きさは $1.6 \times 10^{9} \mathrm{~V} / \mathrm{cm}$
に達し, 水素原子の $1 \mathrm{~s}$ 軌道の電子が原子核から感じる 電場 $\left(5 \times 10^{9} \mathrm{~V} / \mathrm{cm}\right)$ にほぼ匹敵する。このように強い レーザー場において，分子は摂動領域の弱い光の場とは 本質的に大きく異なったふるまいを示す。レーザー場中 の分子では，まず電子がレーザー場から強い擾乱を受 け，これに伴う核間ポテンシャルの変化によって構造変 形がおこる．条件によっては，レーザー偏光方向への分 子軸の配列が誘起されることもある. 多重イオン化はこ れらの過程と平行して進行する。 イオン化の速度(レー 卜)は核間距離によって変化し，平衡位置の 2 倍程度に伸 張したところで最大となることがこれまでの研究で明ら かになっている。これは核間距離が大きくなることに よって, 最外軌道の電子が原子に局在化することに起因 している ${ }^{8-10)}$ 。このため, どの価数の多価イオンが生成 するかはレーザーパルスの強度だけでなく，パルスが照 射されている間にどの程度，分子の核間距離が変化する かに依存する。言い換えれば，このようにして生成した 多価イオンからのクーロン爆発過程は, 強いレーザー場 の中でどのように分子の構造が変形したかを反映するこ とになる。

通常，核運動の時間スケールはフェムト秒からピコ秒 領域なので，レーザーのパルス幅が十分短く $(<10 \mathrm{fs})$, 速やかに多重イオン化を起こすことができればレーザー パルス照射時における分子構造のイメージングが行え る。これをポンプープローブ計測と組み合わせて利用す れば，光反応過程を開始させる励起光パルス (ポンプパ ルス)に対して, クーロン爆発のための強レーザーパル スをプローブパルスとして時刻を変えて分子に照射する ことによって，反応過程における分子ダイナミクスを幾 何学的構造の変化として実時間で追跡できる。こうした アイデアはクーロン爆発過程の研究において早くから提 案されてきたが, 反応を開始させる励起光との同期が難 しいため，多価イオンやフォイルを用いたクーロン爆発 では実現が困難であった。レーザー技術の発展によっ て，高強度でかつ極めて短いパルス幅を持つレーザーパ ルス発生が可能となり，化学反応実時間追跡に向けたこ の新しいアプローチが実現したと言える.

$$
\text { 3. レーザークーロン爆発イメージング }
$$

レーザーによるクーロン爆発イメージングには, サブ 10 フェムト秒領域の高強度極短レーザーパルスが必要で ある。我々のグループでは，中空ファイバとチャープミ ラーからなるパルス圧縮器を用いて実験を行っている (Fig. 2)。フェムト秒レーザー再生増幅器からの出力 (中 心波長 $800 \mathrm{~nm}$ ，エネルギー $1 \mathrm{~mJ} /$ pulse，パルス幅 $35 \mathrm{fs}$ ) は 希ガス $(\mathrm{Ar}, \sim 0.07 \mathrm{MPa})$ を満たした中空ファイバ(コア径 $500 \mu \mathrm{m})$ に導入され，ファイバ内における媒質との非線 形相互作用によって周波数帯域が広がる。同時に正の周 波数チャープ(変調)が生じるが，この周波数チャープは エネルギーが集中するパルス中心部ではほぼ線形である ため，負の周波数分散を持つ鏡 (チャープミラー)に複数 回反射させてこれを補償しパルス圧縮する ${ }^{11,12)}$ 。圧縮後 

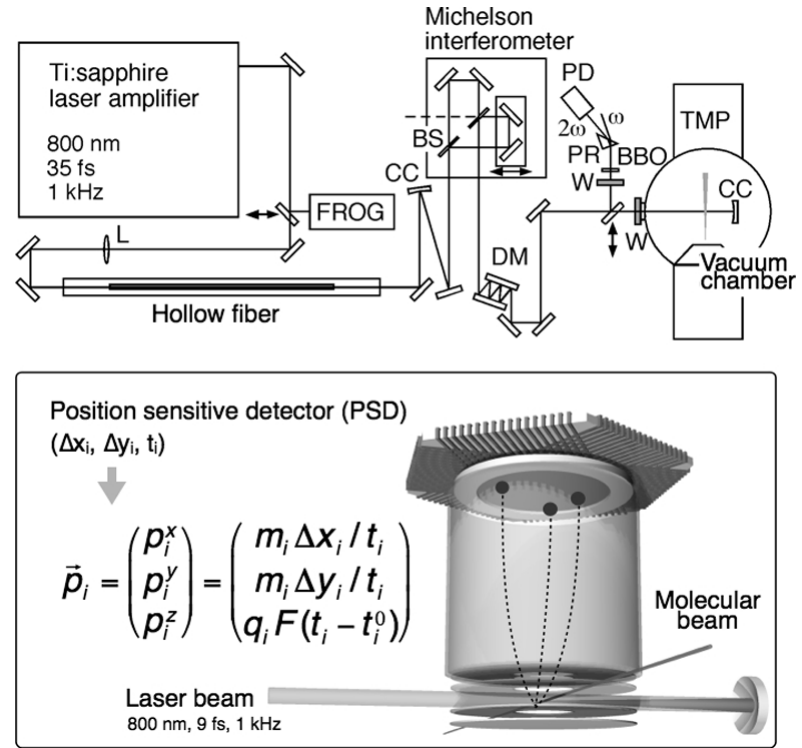

Fig. 2 Laser setup for time-resolved laser Coulomb explosion imaging. CC: concave mirror, BS: beam splitter, DM: dispersive mirror (chirp mirror), W: vacuum-tight window, PD photodiode, PR: prism, TMP: turbo-molecular pump. Coincidence ion momentum imaging apparatus. The momentum $\vec{p}_{i}$ of the $i$-th fragment ion is calculated from the position of the ion at the detector $\left(\Delta x_{\mathrm{i}}, \Delta y_{\mathrm{i}}\right)$ and from the arrival time $t_{\mathrm{i}}$. The ion-extraction electric field is denoted as $F$, and $m_{i}$ and $q_{i}$ are the mass and charge of the fragment ion, respectively.

のエネルギーは $0.4 \mathrm{~mJ} / \mathrm{pulse}$ であり, 適切な光学系を用

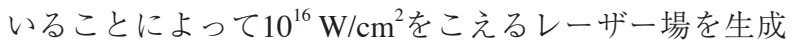
することが可能である

強レーザー場において生成した多価分子イオンからは さまざまな経路に沿ってクーロン爆発がおこる。フラグ メントイオンの運動量に基づいて分子構造を理解するた めには, 解離経路を特定し, それぞれのイオンの持つ運 動量を計測する必要がある。この目的のために, ここで は「コインシデンス運動量画像法」吕を用いた。この手法 は高速位置敏感型検出器 (PSD) を用い, (i) 単一の親分 子イオンから生成するすべてのフラグメントイオンを同 時検出し，（ii）それぞれのイオンについてその運動量を 3次元ベクトルとしてクーロン爆発事象毎に決定する.

これによって, 生成した親分子イオンの価数および解離 経路を指定した上で，各フラグメントイオンの運動量間 の相関に基づいて強レーザー場における分子過程を調べ ることが可能となる.

Fig. 2 に実験装置の概要を示す，分子とレーザー場と の相互作用によって生成したフラグメントイオンは, 速 度写像型電場 ${ }^{14)} に よ っ て P S D(R o e n t d e k ~ G m b H$ 社, HEX80) に導かれる。PSDに到着したイオン毎にその位置 $\left(x_{\mathrm{i}}\right.$, $\left.y_{\mathrm{i}}\right)$ および飛行時間 $\left(t_{\mathrm{i}}\right)$ が記録され, これからその運動量

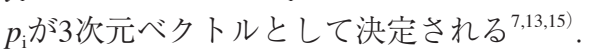

解離経路の特定は, その経路に対応するすべてのイオ ンが同時検出されたクーロン爆発事象を抽出して行う. 単一の親分子からのコインシデンス事象を捉えるために
は，標的分子の数密度を下げ，レーザーパルスあたりの クーロン爆発事象の確率を 1 よりも十分に小さく抑える 必要がある。このため実験は通常 $1 \times 10^{-8} \mathrm{~Pa}$ 程度の高真 空条件下で行う.

こうしたサブ10 fs領域の超短パルスレーザーとコイン シデンス運動量計測法を組み合わせた研究は2003年頃か ら精力的に行われるようになった。 特にクーロン爆発イ メージングに関する研究としては, これまでに $\mathrm{N}_{2}$, $\mathrm{O}_{2}{ }^{16,17)}, \mathrm{D}_{2} \mathrm{O}, \mathrm{SO}_{2}{ }^{18)}, \mathrm{H}_{2} \mathrm{~S}^{19)}, \mathrm{CS}_{2}{ }^{20)}, \mathrm{O}_{3}{ }^{21)}, \mathrm{C}_{2} \mathrm{H}_{2}{ }^{22-24)}$, $\mathrm{CH}_{3} \mathrm{OH}^{25)}$ について報告がなされている。ここでは, 超短 パルス強レーザー場 $\left(9 \mathrm{fs}, 5 \times 10^{15} \mathrm{~W} / \mathrm{cm}^{2}\right)$ における $\mathrm{CS}_{2}$ のクーロン爆発イメージングについて紹介する。この条 件下での $\mathrm{CS}_{2}$ の飛行時間質量スペクトルには7つの解離 イオン種, $\mathrm{CS}^{+}, \mathrm{S}^{+}, \mathrm{S}^{2+}, \mathrm{S}^{3+}, \mathrm{S}^{4+}, \mathrm{C}^{+}, \mathrm{C}^{2+}$, が観測さ れた20).コインシデンス計測を行ったところ, クーロン 爆発過程には2つの異なる2体爆発経路 $(m, n)=(1,1)$, $(1,2)$,

$$
\mathrm{CS}_{2}{ }^{2+} \rightarrow \mathrm{CS}^{m+}+\mathrm{S}^{n+}
$$

の他に, 6 種類の対称な3体クーロン爆発過程 $(p, q, r)=$ $(1,1,1),(1,2,1),(2,1,2),(2,2,2),(3,2,3),(4,2$, 4),

$$
\mathrm{CS}_{2}{ }^{z+} \rightarrow \mathrm{S}^{p+}+\mathrm{C}^{q+}+\mathrm{S}^{r+},
$$

が観測された. Fig. 3にクーロン爆発過程, $\mathrm{CS}_{2}{ }^{10+} \rightarrow \mathrm{S}^{4+}$ $+\mathrm{C}^{2+}+\mathrm{S}^{4+}$ ，によって生成したフラグメントイオンの分 子座標系における運動量分布を示す。各点はクーロン爆 発事象ひとつずつに対応し，それぞれの運動量は原点か らの距離で表されている。比較のために $\mathrm{CS}_{2}$ 基底状態の 分子構造を初期状態として行った古典シミュレーション の結果をプロットした。シミュレーションにおいては,

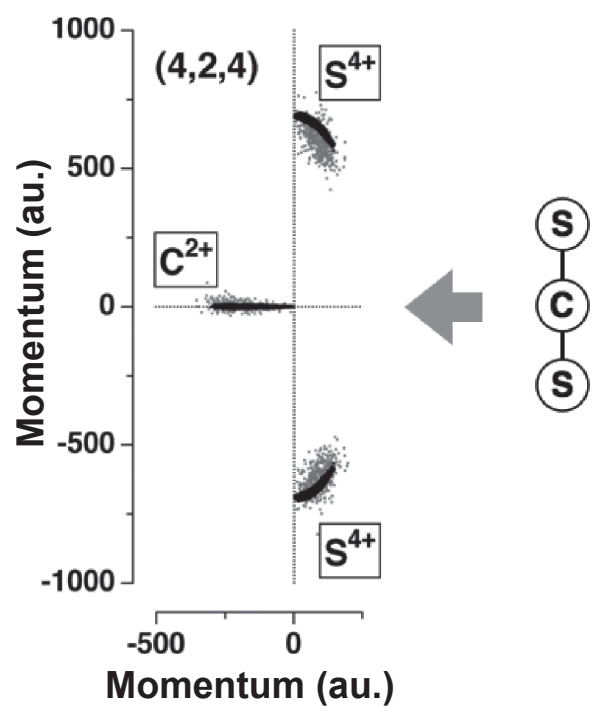

Fig. 3 Coulomb explosion of a "linear" molecule $\mathrm{CS}_{2}$, $\mathrm{CS}_{2}{ }^{10+} \rightarrow \mathrm{S}^{4+}+\mathrm{C}^{2+}+\mathrm{S}^{4+}$, in intense laser fields $\left(9 \mathrm{fs}, 5 \times 10^{15} \mathrm{~W} / \mathrm{cm}^{2}\right)$. Observed (gray) and simulated (black) fragment moments are expressed in the molecular frame. The deviation reflects nuclear dynamics during the ionization and nonCoulombic potentials (see text). 
$\mathrm{CS}_{2}$ 基底状態における零点振動による構造分布を考慮 し，また簡単のためにポテンシャル曲面は各フラグメン トイオン間のクーロン反発のみで決まるとした。観測さ れた運動量分布はシミュレーションによる予想とよい一 致を示し，クーロン爆発に分子構造がその零点分布を含 めて反映されていることがわかる。シミュレーションと のずれは主として動径方向に見られるが、これはレー ザーパルス内で多重イオン化する間に結合距離が伸びて いることに加えて, $\mathrm{CS}_{2}{ }^{10+}$ のポテンシャル曲面が単純な クーロンポテンシャルからずれているためたと考えられ る。後者はより低いイオン価数状態からのクーロン爆発 において顕著である。そのためクーロン爆発経路 $(1,1$, 1)に対して観測された運動量の大きさは単純なクーロン ポテンシャルと考えた場合と比べて $50 \%$ 程度に過ぎな い.また，実験結果はシミュレーションに比べて広い分 布幅を持つが, 同様の傾向は多価イオン衝突によるクー ロン爆発過程においても観測されている。これは, クー ロン爆発には多価イオン分子の複数の電子状態が寄与 し, 電子状態によってクーロンポテンシャルからのずれ がわずかに異なるためだと理解できる. 低いイオン価数 からのクーロン爆発を用いたイメージングは, 精密な構 造決定には不向きであるが, 後述するように大きな構造 変化を伴う反応過程の追跡には十分な精度を持っている 場合が多い.

\section{4. レーザークーロン爆発イメージング による実時間反応追跡}

ポンプープローブ計測においてクーロン爆発のための 強レーザーパルスをプローブパルスとして用いれば，反 応過程における分子ダイナミクスを幾何学的構造の変化 として実時間追跡することができる。これまでに，この アプローチを用いて 2 原子分子や3 原子分子の解離ダイナ ミクスについての研究がいくつか報告されている.ここ ではクーロン爆発イメージングを用いて, 化学結合の組 み替えによる「異性化反応」を実時間追跡した結果につい て紹介する。

\section{1 分子内水素移動反応}

我々の身の回りに存在する物質は様々な分子から構成 されている，通常，原子はある特定の原子と結合し，そ のため分子はある定まった幾何学的構造を持つ。これに 対して, 反応途中の分子は高いエネルギーを持ち, その 構造は極めて短時間で大きくその姿を変える，特に，原 子の中で最も小さい水素の運動は他の原子に比べて極め て高速である。このため分子内での水素移動過程は光放 出過程など競合する他の過程を抑制し, 化学反応の経路 を決定づける重要な役割を果たすことがしばしばある。 実際，水素移動過程は，燃焼あるいは触媒反応など様々 な反応過程に寄与することが知られており，反応過程を 理解する上で重要である ${ }^{26)}$.

2つの水素原子と2つの炭素原子からなるアセチレン分 子 $\left(\mathrm{C}_{2} \mathrm{H}_{2}\right)$ におけるアセチレン型 $(\mathrm{HCCH})$ からビニリデン
型 $\left(\mathrm{CCH}_{2}\right)$ への異性化反応は, 水素移動反応のプロトタ イプとして知られている。 この異性化の時間スケールは 中性 $\mathrm{C}_{2} \mathrm{H}_{2}$ について $40-200 \mathrm{fs}$ 程度 ${ }^{27)}$ ，2価イオン $\mathrm{C}_{2} \mathrm{H}_{2}{ }^{2+}$ で は60 fs以下 ${ }^{28)}$ であることがこれまでの分光計測で示唆さ れている。この異性化反応がどのようにクーロン爆発過 程に反映されるかを調べるために，まずプローブパルス のみを用いた実験を行った．Fig. 4 (a)，（b）に異なるパ ルス幅を持つ強レーザーパルスを用いて観測した3体 クーロン爆発過程 (Fig. 5 (a)) :

$$
\mathrm{C}_{2} \mathrm{H}_{2}^{3+} \rightarrow \mathrm{H}^{+}+\mathrm{C}^{+}+\mathrm{CH}^{+}
$$

についての結果を示す。横軸はフラグメントイオンが持 つ運動エネルギーの総和 $E_{\mathrm{kin}}=\sum\left(p_{i}^{2} / 2 m_{i}\right)$ であり，核間 距離の変化を反映する，ここで， $p_{i}$ および $m_{i}$ は各フラグ メントイオンの運動量と質量である。縦軸は $\mathrm{H}^{+}$と $\mathrm{CH}^{+} の$ 運動量 $p_{1}\left(\mathrm{H}^{+}\right)$と $p_{2}\left(\mathrm{C}^{+}\right)$のなす角 $\theta_{12}$ である. Fig. 4 (c) はこ の運動量角 $\theta_{12}$ が分子座標系における水素原子の位置に よってどのように変化するかを古典シミュレーションに よって調べた結果を示す。これから分子がアセチレン構 造 $(\mathrm{HCCH})$ を保ったままクーロン爆発を起こした場合, 運動量角は $\theta_{12}=0^{\circ}$ 付近の值をとるのに対して, ビニリ デン構造 $\left(\mathrm{CCH}_{2}\right)$ では $\theta_{12} \sim 120^{\circ}$ となることがわかる. $9 \mathrm{fs}$ レーザーパルスを用いて得られた実験結果 (Fig. 4 (a)) は，運動量角が $\theta_{12} \sim 30$ ○でピークを持つ分布を持つこと を示している。この分布はアセチレン基底状態の零点振 動を考慮したシミュレーションによって再現することが でき，こうした短いレーザーパルスを用いた場合はクー ロン爆発まで核運動がほぼ凍結されていることがわか る。一方，パルス幅を $35 \mathrm{fs}$ とた場合，運動量角は大き な $\theta_{12}$ に向けて大きく広がった分布を示す。これは, レーザー場においてビニリデン型への異性化反応が起き

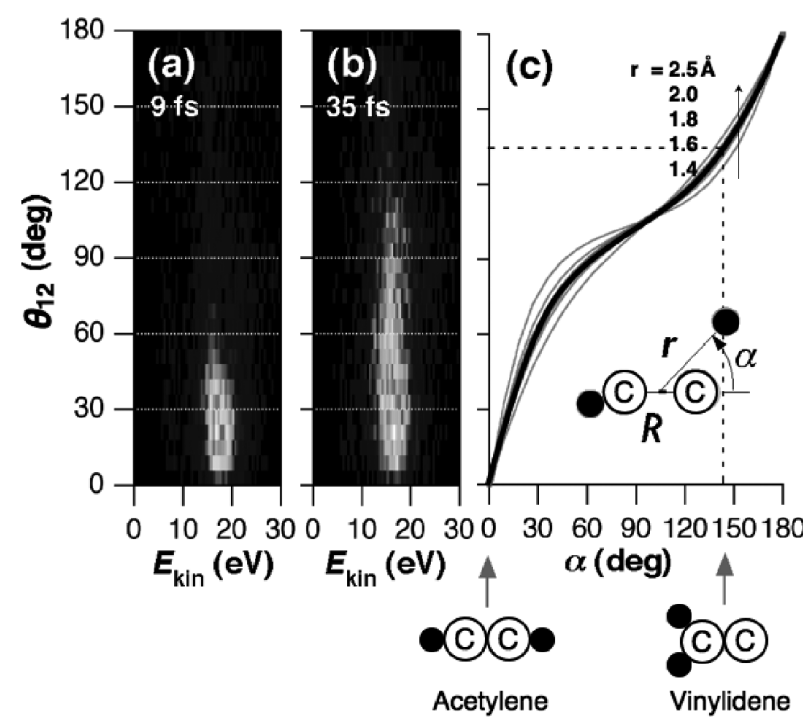

Fig. 4 Dependence of $\theta_{12}-E_{\text {kin }}$ distribution on the laser pulse duration (a) $9 \mathrm{fs}$, (b) $35 \mathrm{fs}\left(8 \times 10^{14} \mathrm{~W} / \mathrm{cm}^{2}\right)$. (c) Momentum angle $\theta_{12}$ plotted against the angular position of hydrogen atom in the molecular frame $\alpha$, calculated by a classical simulation on the threebody explosion in Eq.(3). The C-C distance is fixed to $R=1.20 \AA \AA^{22)}$ 
ていることを意味しており，レーザーパルス幅程度の短 い時間スケールでの水素原子の移動を示唆している.

\section{2 アセチレン異性化反応の実時間追跡}

水素移動は様々な反応過程において重要な役割を果た すことが知られているが，実際に水素原子がどのように 分子内を動き回っているかを分子構造の変化として捉え ることは簡単ではない。これは(i)水素運動の時間ス ケールが100フェムト秒以下と極めて短いこと, (ii) 水 素原子の散乱能が小さく十分な散乱強度が得られないこ との2点から分子構造を決定するための標準的手法とし て用いられてきた(時間分解)X線回折や電子線回折の適 用が困難であったためである。

ここでは，重水素化したアセチレン2価分子イオン $\left(\mathrm{C}_{2} \mathrm{D}_{2}{ }^{2+}\right)$ における水素移動反応のクーロン爆発イメージ ングについて紹介する。 マイケルソン干渉計を用いて, サブ10fsパルスを2つに分割し, 得られた一対の高強度 極短レーザーパルス $\left(9 \mathrm{fs}, 0.13 \mathrm{PW} / \mathrm{cm}^{2}\right)$ をそれぞれポン プ光およびプローブ光として用いる. ポンプ光との相互 作用によって生成した $\mathrm{C}_{2} \mathrm{D}_{2}{ }^{2+} に$ におる水素移動過程は, 時間遅延 $\Delta t$ をおいて導入したプローブ光による $\mathrm{C}_{2} \mathrm{D}_{2}{ }^{3+}$ か らのクーロン爆発過程 :

$$
\mathrm{C}_{2} \mathrm{D}_{2}^{3+} \rightarrow \mathrm{D}^{+}+\mathrm{C}^{+}+\mathrm{CD}^{+}
$$

をモニターすることによって調べた(Fig. 5(b))．特にD+ およびC+口運動量べクトルのなす角 $\theta_{12}$ が分子内におけ る重水素原子の位置を鋭敏に反映することに着目し (Fig. 4参照), その時間発展から水素移動過程の様子を 調べた。 (a)

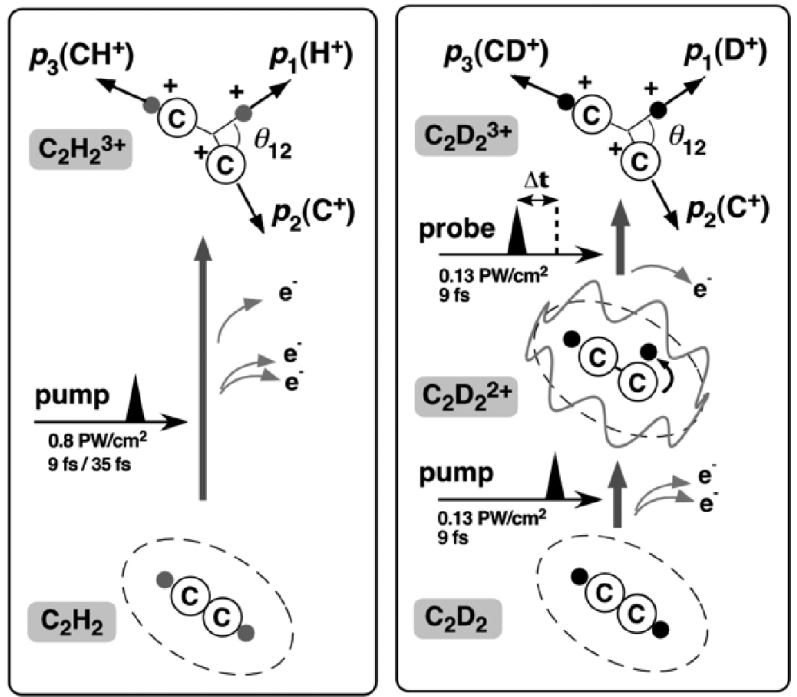

Fig. 5 (a) Three-body Coulomb explosion of $\mathrm{C}_{2} \mathrm{H}_{2}$, $\mathrm{C}_{2} \mathrm{H}_{2}{ }^{3+} \rightarrow \mathrm{H}^{+}+\mathrm{C}^{+}+\mathrm{CH}^{+}$. (b) Pump-probe laser Coulomb explosion for hydrogen migration in acetylene dication. A pump pulse doubly ionizes $\mathrm{C}_{2} \mathrm{D}_{2}$ and triggers the migration of hydrogen. The structural change associated with the migration is monitored by a probe pulse, by three-body Coulomb explosion, $\mathrm{C}_{2} \mathrm{D}_{2}^{3+} \rightarrow \mathrm{D}^{+}+\mathrm{C}^{+}+\mathrm{CD}^{+}$.
Fig. 6に得られた結果を示す。時間遅延 $\Delta t=30 \mathrm{fs}$ にお いては運動量角 $\theta_{12}$ の分布 $\theta_{12}=0^{\circ}$ にピークをもつことが わかる。これは時間遅延が十分小さい場合，ポンプ光に よって生成した $\mathrm{C}_{2} \mathrm{D}_{2}{ }^{2+}$ はアセチレン構造を保ったままで いることを示している，その後分布 $\Delta t$ の増加に伴って変 化し， $\Delta t=90 \mathrm{fs}$ で新しいピークが $\theta_{12} \sim 120^{\circ}$ に観測され た。更に時間がたつと分子アセチレン構造に向けて移動 し， $\Delta t=280 \mathrm{fs}$ で再び $\theta_{12}=0$ にヒピークを示した。 このこ とは，水素原子が片方の炭素サイトから他方へ極めて高 速 ( 90 fs) にシフトした後, 元の炭素サイトへ再移動す ることを意味しており，強レーザーパルスによって生成 したアセチレン2価イオンにおける水素移動反応が再帰 的に起こることが明らかとなった。

4.3 アセチレン異性化反応における水素原子運動相関 複数の水素原子を含む分子に拍いて，水素原子はそれ ぞれ独立に動くのではなく，ある相関を持つことが予想 される，例えばアセチレン異性化反応において，一方の 水素原子が炭素原子間を移動すると，それに応じて他方 の水素原子もその位置を変え, ビニリデン型の配置をと ると考えられる。この運動相関を明らかにするために， プローブ光によって誘起された 4 体クーロン爆発過程

$$
\mathrm{C}_{2} \mathrm{D}_{2}^{4+} \rightarrow \mathrm{D}^{+}+\mathrm{C}^{+}+\mathrm{C}^{+}+\mathrm{D}^{+}
$$

に着目した実験を行った ${ }^{24)}$ ，分子座標系における2つの 重水素原子の位置を独立に調べるために，2つの炭素イ オンの運動量ベクトル $\left(\boldsymbol{p}_{3}{ }^{\prime}, \boldsymbol{p}_{4}{ }^{\prime}\right)$ の差, $\boldsymbol{p}_{34}{ }^{\prime}=\boldsymbol{p}_{3}{ }^{\prime}-\boldsymbol{p}_{4}{ }^{\prime}$, を 用いてC-C結合の方向を近似的に求めた (Fig. 7). 分子座 標系における重水素原子の位置は，それぞれの運動量べ クトルと $\boldsymbol{p}_{34}{ }^{\prime}$ のなす角 $\theta_{1}{ }^{\prime}$ および $\theta_{2}{ }^{\prime}$ に反映される。 3 体過程 の場合と同様，運動量ベクトルはクーロン爆発事象毎に 決定し, 単一の分子についてこれらの運動量角 $\left(\theta_{1}{ }^{\prime}\right.$, $\left.\theta_{2}{ }^{\prime}\right)$ を計算した。

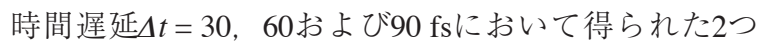
の重水素原子の運動量角 $\theta_{1}{ }^{\prime}$ お よび $\theta_{2}{ }^{\prime}$ の相関を Fig. 8 に示 す。短い時間遅延 $(\Delta t=30 \mathrm{fs})$ においては, $\left(\theta_{1}{ }^{\prime}, \theta_{2}{ }^{\prime}\right)=$ $\left(0^{\circ}, 180^{\circ}\right)$ および $\left(180^{\circ}, 0^{\circ}\right)$ 近傍に強い分布が観測さ れ，C-C結合の向きに沿ってお互いに反対方向に重水素

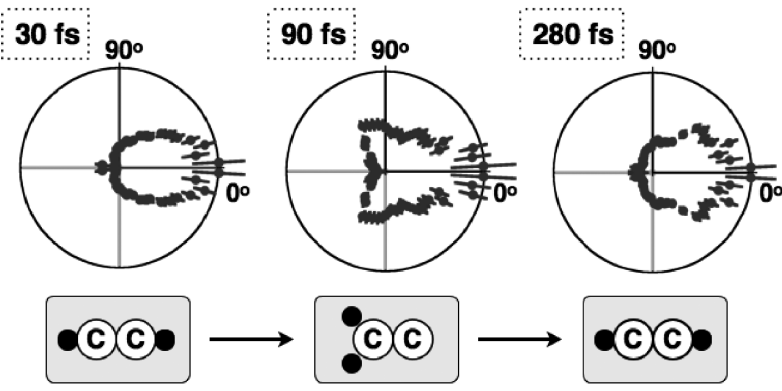

Fig. 6 Hydrogen migration in $\mathrm{C}_{2} \mathrm{D}_{2}{ }^{2+}$. The momentum angle $\theta_{12}$ distribution peaked at $\theta_{12} \sim 0{ }^{\circ}$ at $30 \mathrm{fs}$ exhibits a new peak at $\theta_{12} \sim 120^{\circ}$ at $90 \mathrm{fs}$, and then shifts back to $\theta_{12} \sim 0^{\circ}$, showing that the deuterium atom rapidly migrates from one carbon site to the other within $90 \mathrm{fs}$ and then migrates back to the acetylene configuration in $280 \mathrm{fs}$. 
(a)

(b)
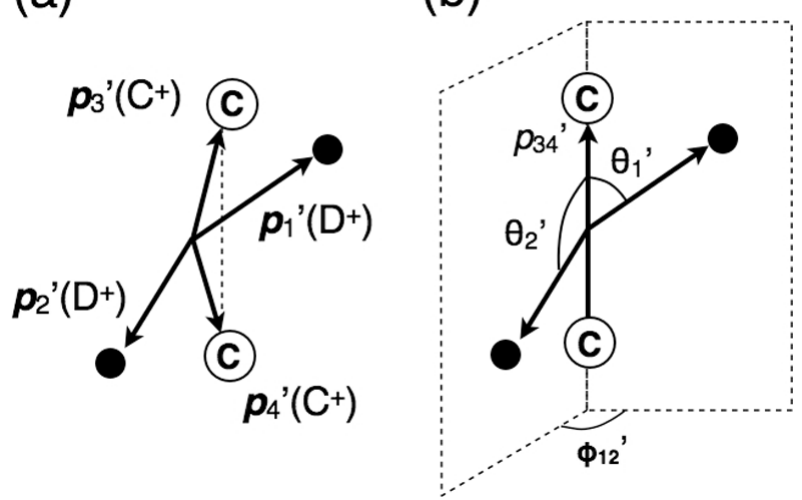

Fig. 7 Definition of (a) the momentum angle $\theta_{12}{ }^{\prime}$ and (b) the polar $\left(\theta_{1}{ }^{\prime}, \theta_{2}{ }^{\prime}\right)$ and azimuthal $\left(\phi_{12}{ }^{\prime}\right)$ angles. Here $\boldsymbol{p}_{34}{ }^{\prime}$ is defined as the difference between $\boldsymbol{p}_{3}{ }^{\prime}$ and $\boldsymbol{p}_{4}{ }^{\prime}$, i.e., $\boldsymbol{p}_{34}{ }^{\prime}=\boldsymbol{p}_{3}{ }^{\prime}-\boldsymbol{p}_{4}{ }^{\prime}$.

イオンが放出されることがわかる。このことは，2つの 重水素原子が元の炭素原子近傍に存在し, アセチレン構 造がほほ保たれていることを示している。一方, $\Delta t=90 \mathrm{fs} に お い て は \theta_{1}{ }^{\prime}=\theta_{2}{ }^{\prime}=90^{\circ}$ 近傍に新しい成分が観 測され, 重水素原子が元の炭素原子から他方の炭素原子 へと移動していることがわかる。この際, 図には対角線 上に強い分布が見られ， $\theta_{1}{ }^{\prime}$ の ${ }^{\circ}$ からの増加に伴って $\theta_{2}{ }^{\prime}$ が $\theta_{2}{ }^{\prime}=180^{\circ}-\theta_{1}{ }^{\prime}$ を満たすように減少することがわか る. これは2つの水素原子が分子内で強い相関を持って 運動していることを示している ${ }^{24)}$.

\section{5. おわりに}

今回の研究で用いた手法は, 反応を開始させる光の波 長や強度を変えることによって, 様々な分子の反応過程
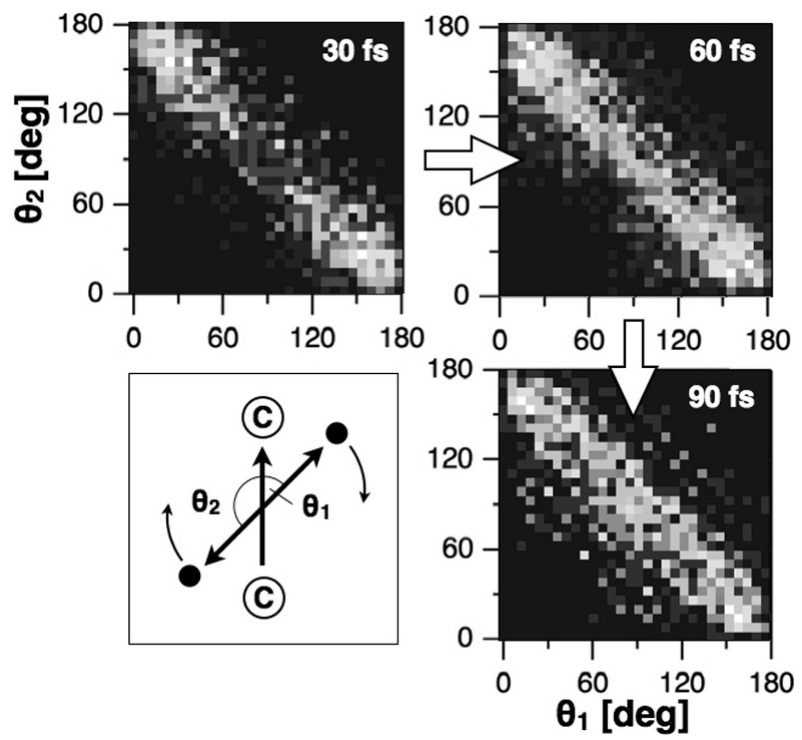

Fig. 8 Two-dimensional correlation map between the polar angles $\theta_{1}{ }^{\prime}$ and $\theta_{2}{ }^{\prime}$ obtained at $\Delta t=30 \mathrm{fs}$, $90 \mathrm{fs}$, and $280 \mathrm{fs}$, showing correlated dynamics of two hydrogen atoms in $\mathrm{C}_{2} \mathrm{D}_{2}{ }^{2+}$.
の追跡に応用が可能である．極限的な時間分解能を持つ アト秒パルスは主として極紫外あるいは軟X線領域で得 られるため ${ }^{29-32)}$, クーロン爆発を誘起させるプローブと して有効に用いることができる。レーザークーロン爆発 イメージングは $\mathrm{CH}_{2} \mathrm{Cl}_{2}{ }^{33)}$ の様な比較的大きな分子への展 開が進められており, 反応過程における分子の構造変化 について新たな研究が進むことによって, 反応機構のよ り深い理解と高精度な反応制御に向けた新たな指針が得 られると期待される。本稿で紹介したクーロン爆発イ メージングによる水素移動反応の実時間追跡は, 名古屋 大学松田 晃孝助教, 伏谷 瑞穂助教, 理研高橋 栄治先任 研究員との共同研究による成果である.

\section{参考文献}

1) A. H. Zewail: Angew. Chem. Int. Ed. 39 (2000) 2586.

2) H. Ihee, V. A. Lobastov, U. M. Gomez, B. M. Goodson, R. Srinivasan, C.-Y. Ruan, and A. H. Zewail: Science 291 (2001) 458.

3) B. J. Siwick, J. R. Dwyer, R. E. Jordan, and R. J. D. Miller: Science 302 (2003) 1382.

4) H. Ihee, M. Lorenc, K. T. Kim, Q. Y. Kong, M. Cammarata, J. H. Lee, S. Bratos, and M. Wulff: Science 309 (2005) 1223.

5) L. J. Frasinski, K. Codling, and P. Hatherly: Phys. Rev. Lett. 58 (1987) 2424.

6) J. H. Posthumus: Rep. Prog. Phys. 67 (2004) 623.

7) A. Hishikawa and K. Yamanouchi: in Progress in Ultrafast Intense Laser Science II, ed. K. Yamanouchi, S. L. Chin, P. Agostini, and G. Ferrante (Springer, Heidelberg, 2006) p.1.

8) T. Zuo and A. D. Bandrauk: Phys. Rev. A 52 (1995) R2511.

9) T. Seideman, M. Y. Ivanov, and P. B. Corkum: Phys. Rev. Lett. 75 (1995) 2819.

10) K. Codling and L. J. Frasinski: J. Phys. B 26 (1993) 783.

11) M. Nisoli, S. De Silvestri, O. Svelto, R. Szipocs, K. Ferencz, C. Spielmann, S. Sartania, and F. Krausz: Opt. Lett. 22 (1997) 522.

12) S. Sartania, Z. Cheng, M. Lenzner, G. Tempea, C. Spielmann, F. Krausz, and K. Ferencz: Opt. Lett. 22 (1997) 1562.

13) H. Hasegawa, A. Hishikawa, and K. Yamanouchi: Chem. Phys. Lett. 349 (2001) 57.

14) A. T. J. B. Eppink and D. H. Parker: Rev. Sci. Instrum. 68 (1997) 3477.

15) J. Ullrich, R. Moshammer, A. Dorn, R. Dörner, L. P. H. Schmidt, and H. Schmidt-Böcking: Rep. Prog. Phys. 66 (2003) 1463.

16) E. Baldit, S. Saugout, and C. Cornaggia: Phys. Rev. A 71 (2005) 021403.

17) C. Cornaggia: Laser Phys. 19 (2009) 1660.

18) F. Legare, K. F. Lee, I. V. Litvinyuk, P. W. Dooley, S. S. Wesolowski, P. R. Bunker, P. Dombi, F. Krausz, A. D. Bandrauk, D. M. Villeneuve, and P. B. Corkum: Phys. Rev. A 71 (2005) 013415 .

19) A. Hishikawa, E. J. Takahashi, and A. Matsuda: Phys. Rev. Lett. 97 (2006) 243002.

20) A. Matsuda, E. J. Takahashi, and A. Hishikawa: unpublished.

21) A. Matsuda, E. J. Takahashi, and A. Hishikawa: J. Chem. Phys. 127 (2007) 114318.

22) A. Hishikawa, A. Matsuda, E. J. Takahashi, and M. Fushitani: J. Chem. Phys. 128 (2008) 084302.

23) A. Hishikawa, A. Matsuda, M. Fushitani, and E. J. Takahashi: Phys. Rev. Lett. 99 (2007) 258302.

24) A. Matsuda, M. Fushitani, E. J. Takahashi, and A. Hishikawa: Chem. Phys. Phys. Chem. 13 (2011) 8697.

25) R. Itakura, P. Liu, Y. Furukawa, T. Okino, K. Yamanouchi, and H. Nakano: J. Chem. Phys. 127 (2007) 104306.

26) H. F. Schaefer III: Acc. Chem. Res. 12 (1979) 288.

27) K. M. Ervin, J. Ho, and W. C. Lineberger: J. Chem. Phys. 91 (1989) 5974

28) T. Osipov, C. L. Cocke, M. H. Prior, A. Landers, T. Weber, O. Jagutzki, L. Schmidt, H. Schmidt-Böcking, and R. Dörner: Phys. 
Rev. Lett. 90 (2003) 233002.

29) P. B. Corkum and F. Krausz: Nat. Phys. 3 (2007) 381.

30) P. H. Bucksbaum: Science 317 (2007) 766.

31) E. Goulielmakis, V. S. Yakovlev, A. L. Cavalieri, M. Uiberacker, V.

Pervak, A. Apolonski, R. Kienberger, U. Kleineberg, and F.
Krausz: Science 317 (2007) 769.

32) H. Kapteyn, O. Cohen, I. Christov, and M. Murnane: Science $\mathbf{3 1 7}$ (2007) 775 .

33) J. Gagnon, K. F. Lee, D. M. Rayner, P. B. Corkum, and V. R. Bhardwaj: J. Phys. B 41 (2008) 215104.

\section{レーザーワード}

クーロン爆発イメージング (laser Coulomb explosion imaging)

強レーザーパルス照射や多価イオン衝突によって生成 るため, イオン運動量を計測することによって分子構造 した多価分子イオンからの強いクーロン反発による速や のスナップショットが得られる。ポンプープローブ計測 かな解離 $=\lceil$ 「ロン爆発」を利用した分子構造の可視 化法. クーロン爆発によって生成したフラグメントイオ と組み合わせることによって, 反応過程における分子ダ ンの運動量ベクトルは爆発直前の分子構造によって決ま イナミクスを構造の変化として捉えることができる.

(菱川明栄) 